\title{
SunLine Expands Horizons with Fuel Cell Bus Demo
}

\section{SUNLINE TRANSIT AGENCY}

is a joint powers authority that provides public transit and community services to California's Coachella Valley. Headquartered in Thousand Palms, California, SunLine's service area encompasses more than 1,100 square miles and includes nine member cities (Desert Hot Springs, Palm Springs, Cathedral City, Rancho Mirage, Palm Desert, Indian Wells, La Quinta, Indio, and Coachella), as well as Riverside County. The agency's fleet covers 12 routes and serves 320,000 permanent residents and 3.4 million tourists annually.

In December 2005, SunLine placed a prototype hybrid fuel cell transit bus in revenue service. SunLine's prototype vehicle was purchased as part of a four-bus procurement by Alameda-Contra Costa Transit District (AC Transit), based in Oakland, California. AC Transit has three buses in demonstration in its service area. The hot, dry desert environment in SunLine's territory will help further testing of the performance of fuel cell buses in multiple climates.

SUNLINE WAS AN EARLY ADOPTER of alternative fuels for bus operations. In 1994, it converted its entire bus fleet to compressed natural gas (CNG). The agency's fleet currently includes 48 full-size transit buses (40-foot), five mid-size transit buses (29-foot), 23 paratransit vehicles, and 35 light- and medium-duty support vehicles - all of which operate on CNG (a few operate on a blend of CNG and hydrogen).

Since the early 1990s, SunLine has pursued an aggressive course to build a fleet of clean fuel vehicles. After replacing its fleet with CNG buses, SunLine has continued to look for ways to further reduce or eliminate emissions. The agency has participated in many projects to evaluate advanced technologies, including buses that run on a hydrogen/CNG blend, fuel cells, and hybrid hydrogen internal combustion engines. Because of the experience gained by testing prototype fuel cell buses, SunLine is uniquely qualified to demonstrate these advanced buses.

The prototype fuel cell bus in service at SunLine is the result of a collaboration between UTC Power, ISE Corporation, and
Van Hool. The bus uses a fuel cell power system manufactured by UTC Power in a hybrid electric drive system designed by ISE. The original design of the Van Hool A330 transit bus chassis was redesigned to integrate the fuel cell system. The bus has a low floor from front to back and three doors for easy passenger boarding.

\section{ISE'S HYBRID SYSTEM is}

a series configuration, meaning the powerplant is not mechanically coupled to the drive axle. The powerplant and energy storage system work together to provide electricity to two electric drive motors, which are coupled to the driveline through a combining gearbox. When the bus needs extra power, the powerplant and energy storage provide power to the drive motors. When the power requirements of the bus are low, the powerplant provides power and recharges the energy storage system.

The hybrid system is also capable of regenerative braking, which captures the energy typically expended during braking and uses it to recharge the energy storage system. Each component of the propulsion system is carefully controlled through an ISE-developed operating system.

ISE designed the system to be flexible. Depending on a client's needs, a variety of powerplants and energy storage

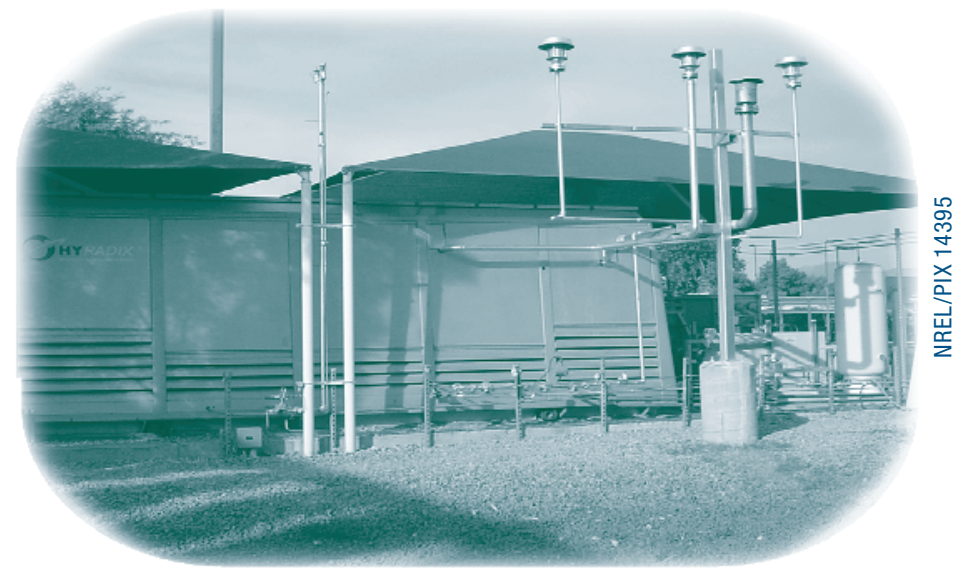

A natural gas autothermal reformer by HyRadix produces hydrogen for the fuel cell bus at SunLine. 


\section{SUNLINE FUEL GELL BUS FACTS}

\begin{tabular}{|c|c|}
\hline Bus Chassis & Van Hool, A330 Fuel Cell \\
\hline Model Year & 2005 \\
\hline Length/Width/Height & $40 \mathrm{ft} / 102 \mathrm{in} / 11 \mathrm{ft}, 5 \mathrm{in}$ \\
\hline GVWR/Curb Weight & $43,240 \mathrm{lb} / 36,000 \mathrm{lb}$ \\
\hline Passenger Capacity & $\begin{array}{l}30 \text { seated (or } 26 \text { seated, plus two } \\
\text { wheelchairs), } 18 \text { standing }\end{array}$ \\
\hline Drive System & ISE ThunderVolt $\circledast$ hybrid drive system \\
\hline Electric Propulsion & $\begin{array}{l}\text { Siemens ELFA Drive; two AC induction } \\
\text { motors, } 85 \mathrm{~kW} \text { each ( } 170 \mathrm{~kW} \text { total) }\end{array}$ \\
\hline Powerplant & $\begin{array}{l}\text { UTC Power PureMotionTM 120, PEM fuel cell } \\
\text { system, } 120 \text { kW continuous power }\end{array}$ \\
\hline Accessories & $\begin{array}{l}\text { Electrically driven for air, heating, and air } \\
\text { conditioning }\end{array}$ \\
\hline Fuel/Storage & $\begin{array}{l}\text { Gaseous hydrogen, } 50 \mathrm{~kg} \text { at 5,000 psi, type III } \\
\text { tanks by SCl }\end{array}$ \\
\hline Energy Storage & $\begin{array}{l}\text { ZEBRA® (nickel sodium chloride), three } \\
\text { modules, } 32 \mathrm{~kW} \text { ( } 95 \mathrm{~kW} \text { total), } 53 \mathrm{kWh} \\
\text { storage }\end{array}$ \\
\hline Brakes & Regenerative braking, four-wheel disc brakes \\
\hline Range & 250-300 miles \\
\hline Emissions & Zero \\
\hline
\end{tabular}

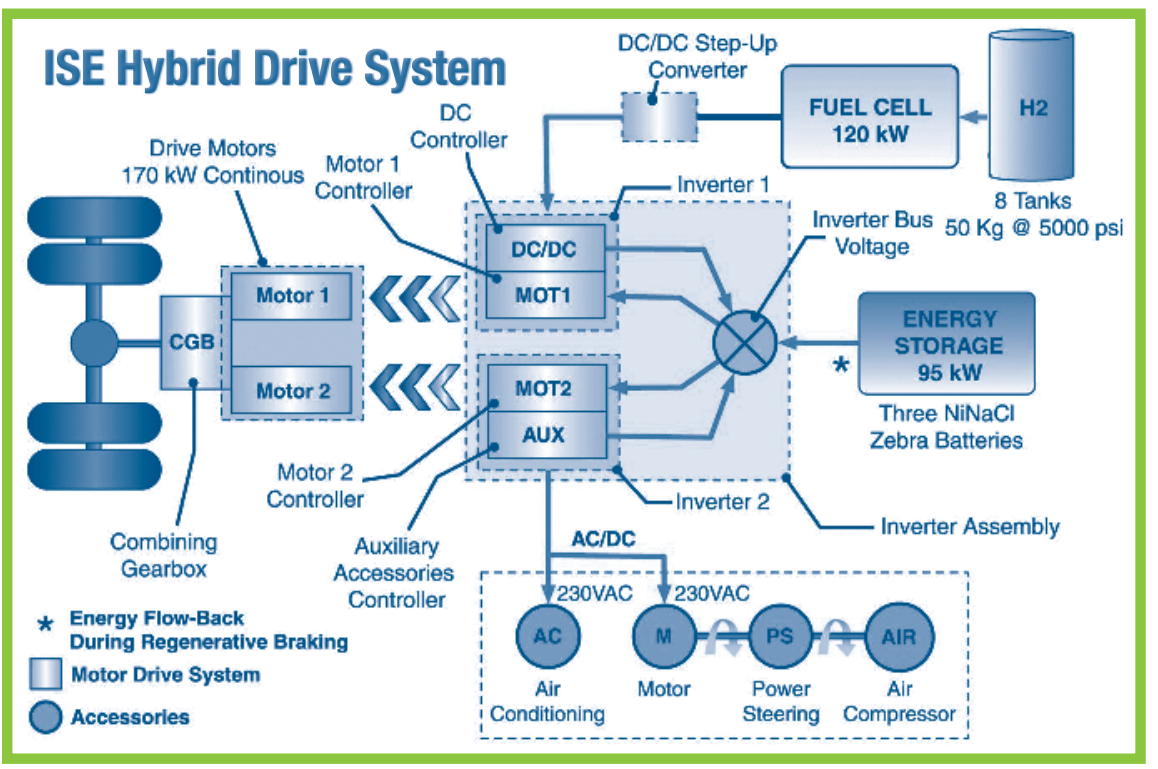

options can be integrated into the system. The bus at SunLine has a fuel cell powerplant and three ZEBRA ${ }^{\circledR}$ (sodium nickel chloride) batteries.

The primary power source for the hybrid system is UTC Power's PureMotion $^{\mathrm{TM}} 120 \mathrm{~kW}$ proton exchange membrane (PEM) fuel cell system. UTC Power's fuel cells operate at near-ambient pressure, which eliminates the need for a compressor. This not only increases the efficiency of the system but results in a quieter operation.

SUNLINE IS CURRENTLY COLLABORATING with the U.S. Department of Energy's (DOE) Hydrogen, Fuel Cells \& Infrastructure Technologies (HFCIT) Program on the evaluation of the fuel cell bus. The agency will run the bus in revenue service for at least two years. During this time, DOE's National Renewable Energy Laboratory (NREL) will collect and analyze performance and operations data.

This evaluation is one of several DOE projects that supports the research and development of highly efficient, low- or zero-emission fuel cell power systems and is consistent with HFCIT Program goals. Information gathered during the demonstration will help researchers assess the status of the technology and aid fleets in making informed purchase decisions. Results will also be fed back into the research and development process to focus future resources, as appropriate.

\section{SunLine Partners \\ SunLine has the support of several partners in the demonstration. They include: \\ - Funding partners: Federal Transit Administration, California Air Resources Board (CARB) \\ - Demonstration partners: AC Transit and Golden Gate Bridge, Highway, and Transportation District \\ - Technology partners: ISE (hybrid propulsion system), UTC Power (fuel cell), Van Hool (bus chassis), HyRadix (natural gas reformer) \\ - Technical evaluation partner: NREL}

\section{Contacts}

SunLine Transit Agency

Tommy Edwards

Director of Maintenance

760-343-3456, ext. 312

tedwards@sunline.org

National Renewable Energy Laboratory

Leslie Eudy

Senior Project Leader

303-275-4412

leslie_eudy@nrel.gov

Produced by the

National Renewable Energy Laboratory (NREL)

NREL is a U.S. Department of Energy National Laboratory

Operated by Midwest Research Institute • Battelle
Web Sites

SunLine: www.sunline.org

ISE: www.isecorp.com

UTC Power: www.utcpower.com

Van Hool: www.vanhool.com

DOE: www.eere.energy.gov/hydrogenandfuelcells

NREL: www.nrel.gov/vehiclesandfuels/fleettest

CARB: www.arb.ca.gov/homepage.htm

California Fuel Cell Partnership: www.cafcp.org

This project was funded in part by a grant from Chevron.
For more information contact:

EERE Information Center

1-877-EERE-INF (1-877-337-3463)

www.eere.energy.gov

\section{A Strong Energy Portfolio for a Strong America}

Energy efficiency and clean, renewable energy will mean a stronger economy, a cleaner environment, and greater energy independence for America. Working with a wide array of state, community, industry, and university partners, the U.S. Department of Energy's Office of Energy Efficiency and Renewable Energy invests in a diverse portfolio of energy technologies.

\section{DOE/G0-102006-2287 - May 2006}

